\title{
The influence of obesity on biological agents treatment response in psoriatic arthritis: HUR-BIO real life results
}

\author{
Obezitenin psöriyatik artritte biyolojik ajan tedavi yanıtı üzerindeki etkisi: HUR-BIO gerçek yașam sonuçları
}

\author{
(1) Bayram Farisoğulları, @ Gözde Kübra Yardımcı, (1) Alper Sarı, (1) Berkan Armağan, @ Emre Bilgin,

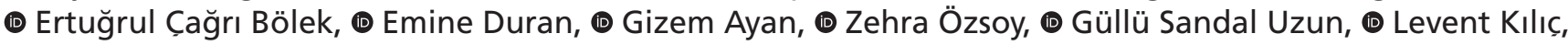

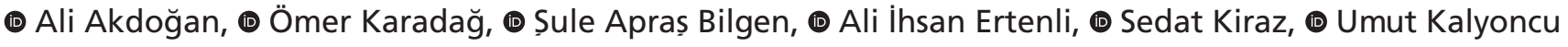

Hacettepe University Faculty of Medicine, Department of Internal Medicine, Division of Rheumatology, Ankara, Turkey

\begin{abstract}
Objective: This study aimed to evaluate the effect of obesity on demographic and clinical features, disease activity indices, and the retention rates of biological disease-modifying antirheumatic drugs (bDMARDs) in psoriatic arthritis (PsA) patients in Hacettepe University Rheumatology Biologic Registry (HUR-BIO).

Methods: Patients who were enrolled in the HUR-BIO PSA registry were included. Until February 2020, HUR-BIO PsA registry enrolled 469 patients. Body mass index $\geq 30$ was defined as obesity. Age- and sexmatched 170 obese and 170 non-obese patients were included in the final analysis. Demographic, clinical, laboratory, and therapeutic data were collected from this database.

Results: The obese group was significantly older at the age of psoriasis diagnosis and had lower PsA disease duration than the non-obese group. While there was no difference between the two groups in terms of axial involvement, peripheral involvement (ever), smoking (ever), HLA-B27 positivity, uveitis, inflammatory bowel disease, use of conventional synthetic disease-modifying antirheumatic drugs (csDMARDs) and steroid, and distribution of first and last bDMARDs, diabetes mellitus and hypertension were more common in the obese group. Several patientreported outcomes (PROs) were significantly higher in the obese group than in the non-obese group at the onset of bDMARDs. However, there was no difference in terms of change in PROs from baseline and significant treatment response at the last visit of the obese and nonobese PsA patients. There was no significant difference between the PsA subgroups in the retention rates of the first bDMARDs. However, it was very close to the significance value (log-rank, $p=0.055$ ).

Conclusion: There was no significant difference in treatment responses between the groups, although baseline disease activity and functions were worse in the obese PsA group than in the the non-obese group. In obese PsA patients, bDMARDs drug retention appears to be worse, although not significant at borderline. Weight loss in obese PsA patients may positively affect the inflammatory burden, retention of bDMARDs and functional parameters.
\end{abstract}

Keywords: Psoriatic arthritis, obesity, bDMARDs, outcome measures, real-life, retention rate

\begin{abstract}
Öz
Amaç: Bu çalıșmada, Hacettepe Üniversitesi Romatoloji Biyolojik Veritabanı'nda (HUR-BIO) kayıtlı psöriyatik artrit (PSA) hastalarında obezitenin demografik ve klinik özelliklere, hastalık aktivite indekslerine ve biyolojik hastalık modifiye edici antiromatizmal ilaçların (bDMARD) ilaçta kalım oranlarına etkisinin değerlendirilmesi amaçlanmıștır.
\end{abstract}

Yöntem: Çalıșmaya HUR-BIO PsA veri tabanına kayıtlı hastalar dahil edildi. Subat 2020'ye kadar HUR-BIO PsA veritabanında kayıtlı 469 hasta vardı. Vücut kitle indeksi $\geq 30$ obezite olarak tanımlandı. Son analize yas ve cinsiyet eșleștirilmiș 170 obez ve 170 obez olmayan PsA hastaları dahil edildi. Demografik, klinik, laboratuvar ve terapötik veriler bu veri tabanından toplanmıștır.

Bulgular: Obez grubun obez olmayan gruba göre psöriazis tanı yașı istatistiksel anlamlı olarak daha yüksek ve PsA hastalık süresi daha kısa idi. İki grup arasında aksiyel tutulum, periferik tutulum (hastalık süresince), sigara kullanımı (hayatı boyunca),HLA-B27 pozitifliği, üveit ve inflamatuvar barsak hastalığı görülmesi, konvansiyonel sentetik hastalık modifiye edici antiromatizmal ilaç (csDMARD) ve steroid kullanımı, ilk ve son bDMARD'ların dağılımı açısından anlamlı bir fark bulunmazken diyabetes mellitus ve hipertansiyon obez grupta obez olmayan gruba göre anlamlı olarak daha yaygındı. bDMARD bașlangıcında bazı hasta ölçekli sonlanım ölçütleri, obez grupta obez olmayan gruba göre anlamlı derecede daha yüksekti. Bununla birlikte, obez ve obez olmayan PsA hastalarının son vizitlerindeki hasta ölçekli sonlanım ölçütlerinde bașlangıca göre değișiklik açısından ve anlamlı tedavi yanıtı açısından bir fark yoktu. Illk bDMARD'ların ilaçta kalım oranlarında PsA alt grupları arasında anlamlı bir fark olmamasına rağmen anlamlılık değerine çok yakındı (log-rank, p=0,055)

Sonuç: Bazal hastalık aktivitesi ve fonksiyonları obez PsA grubunda obez olmayan gruba göre daha kötü olmasına rağmen, gruplar arasında tedavi yanıtlarında anlamlı bir fark yoktu. Obez PsA hastalarında, sınırda anlamlı olmamasına rağmen bDMARD'ların ilaç kalımı daha kötü görünmektedir. Obez PsA hastalarında kilo kaybı, inflamatuvar yükü, fonksiyonel parametreleri ve bDMARD'lerin ilaç kalımını pozitif yönde etkileyebilir.

Anahtar Kelimeler: Psöriyatik artrit, obezite, bDMARD, sonuç ölçütleri, gerçek hayat, ilaçta kalım

\section{İletișim / Correspondence:}

Bayram Farisoğulları MD, Hacettepe University Faculty of Medicine, Department of Internal Medicine, Division of Rheumatology, Ankara, Turkey Tel.: +90 5065042017 E-posta: bayramfarisogullari@gmail.com ORCID ID: orcid.org/0000-0002-9394-1103

Gelis Tarihi/Received: 05.08.2021 Kabul Tarihi/Accepted: 18.10.2021

Atıf / Cite this article as: Farisoğulları B, Yardımcı GK, Sarı A, Armağan B, Bilgin E, Bölek EC, Duran E, Ayan G, Özsoy Z, Sandal Uzun G, Kılıc L, Akdoğan A, Karadağ

Ö, Apraș Bilgen Ș, Ertenli Ali, Kiraz S, Kalyoncu U. The influence of obesity on biological agents treatment response in psoriatic arthritis: HUR-BIO real life results.

Ulus Romatol Derg 2021;13(3):107-115

๑Telif Hakkı 2021 Türkiye Romatoloji Derneği, Ulusal Romatoloji Dergisi, Galenos Yayınevi tarafından basılmıștır.

${ }^{\odot}$ Copyright 2021 by the Turkish Society for Rheumatology / Journal of Turkish Society for Rheumatology published by Galenos Publishing House. 


\section{Introduction}

Biological agents are the milestone in the treatment of psoriatic arthritis (PsA) as other inflammatory rheumatic diseases. One of the factors affecting the success of the treatment of PsA with biologic agents is comorbidity. ${ }^{[1,2]}$ One of the common comorbidities of PsA is obesity. ${ }^{[3]}$ In addition to increasing risk of PsA development, ${ }^{[4,5]}$ obesity also increases disease activity and negatively affects the treatment response in PsA patients. ${ }^{[6-8]}$ This is due to the increased inflammatory load due to the secretion of proinflammatory cytokines such as tumor necrosis factor-alpha (TNF $\alpha)$ and interleukin (IL)-6 and adipokines especially leptin from adipose tissue. ${ }^{[9]}$ Although many studies have shown an association between obesity and disease activity, few studies have investigated treatment response and particularly drug retention in PsA patients using biological disease-modifying antirheumatic drugs (bDMARDs).

The primary objective of the current study was to compare obese PsA patients with non-obese PsA patients using bDMARDs in the Hacettepe University Rheumatology Biologic Registry (HUR-BIO) cohort in terms of demographic, clinical, disease activity, and bDMARDs retention rates.

\section{Materials and Methods}

\section{Study Population}

The present study included patients who were enrolled in HUR-BIO ${ }^{[10]}$ HUR-BIO is a single and independent data recording system of bDMARDs treatment, established in 2005 and has been prospective since 2012. In HUR-BIO, up until February 2020, there were a total of 469 PsA patients according to the clinical decision of a rheumatologist at any time during their treatment periods.

Body mass index (BMI) formula, a simple calculation with weight and height measure, was used to calculate body fat measure. The formula is BMI $\mathrm{kg} / \mathrm{m}^{2}$ where $\mathrm{kg}$ is a person's weight in kilograms and $\mathrm{m}^{2}$ is his/her height in meters squared. ${ }^{[11]}$ The value obtained from the calculation of BMI was used to categorize whether a person was obese or non-obese depending on what range the value fell, $\geq 30$ or $<30$, respectively. ${ }^{[12]}$

Out of 469 patients, 441 patients with BMI data at the onset of bDMARDs treatment were included. There were 187 (42\%) obese and 254 (58\%) non-obese patients. The obese group and non-obese group were matched according to age and gender. One hundred and seventy obese and 170 non-obese patients were included in the final analysis (Figure 1).

\section{Data Collection}

\section{Demographic Data}

We included patients with at least one follow-up visit in this study. Demographic and clinical data were collected from HUR-BIO PsA database including gender, age at diagnosis, disease duration, PsA or family history of psoriasis, HLA-B27 positivity, uveitis, inflammatory bowel disease (IBD), use of steroid or conventional synthetic disease-modifying antirheumatic drugs (csDMARDs) before bDMARDs treatment and 28 swollen/tender joint counts (SJC/TJC).

\section{Assessment of Disease Activity and Efficacy}

Data were collected from patients with at least 1 followup visit to assess disease activity and bDMARDs efficacy: Erythrocyte sedimentation rate (ESR), C-reactive protein (CRP), Bath Ankylosing Spondylitis Disease Activity Index (BASDAI), ${ }^{[13]}$ Bath Ankylosing Spondylitis Functional Index (BASFI), ${ }^{[14]}$ Patient Global Assessment of Disease Activity (PGA)- Visual Analogue scale (VAS), ${ }^{[15]}$ BASDAI50 response, ${ }^{[16]}$ Disease Activity Score-28 joint (DAS28), ${ }^{[17]}$ Psoriatic Arthritis Impact of Disease 12-item questionnaire $\left(\right.$ PSAID-12) ${ }^{[18]}$ and Disease Activity index for Psoriatic Arthritis-28 joint score (DAPSA-28 ${ }^{[19]}$ were evaluated.

ESR, CRP, DAS28, BASDAI, DAPSA-28, and PSAID-12 were compared in both obese and non-obese groups before starting bDMARDs treatment and in the last control visit for patients continuing bDMARDs treatment. In addition, BASDAI50 response and significance of Health Assessment Questionnaire Disability Index (HAQ-DI) score were assessed in the last visit.

According to the baseline evaluation, at least 50\% decrease in DAPSA28, ${ }^{[20]} 3$ units and above decrease in PSAID-12 score, ${ }^{[21]} 1.2$ units and above decrease in DAS-

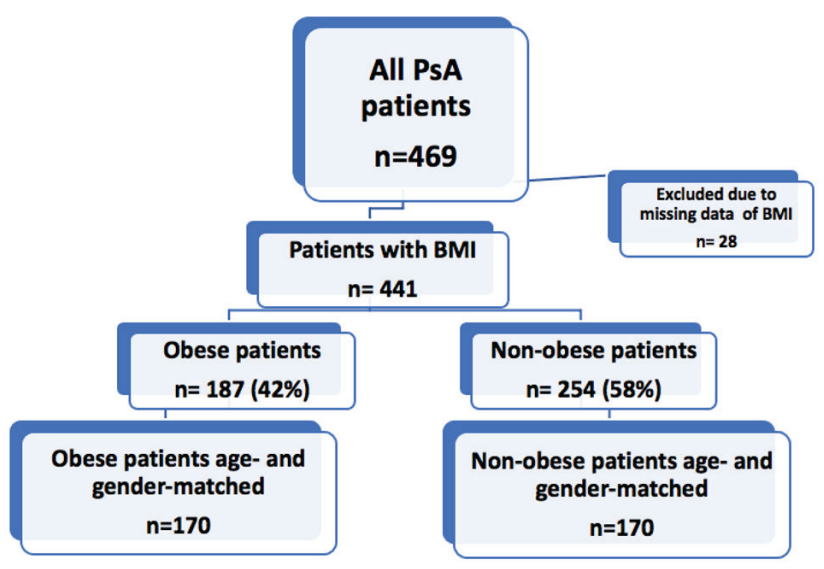

Figure 1. Flow chart of PsA patients in the study PsA: Psoriatic arthritis 
$28,{ }^{[22]} 2$ units and above and/or at least $50 \%$ decrease in BASDAI, ${ }^{[23]}$ and a decrease of $20 \mathrm{~mm}$ and above in PGAVAS $^{[21]}$ were accepted as a favorable response to bDMARDs treatment.

In addition to evaluating the disease activity, HAQ-DI score $^{[24]}$ was evaluated to determine the effects on patients' functional status. For this, an improvement of 0.22 units $^{[25]}$ and above in HAQ-DI score in the last visit compared to the first visit, and HAQ-DI score $<0.5^{[26]}$ in the last visit were compared in the obese and non-obese groups.

Patients were divided into groups as remission, low disease activity (LDA), moderate disease activity, and high disease activity (HDA) according to DAS-28 $8^{[27]}$ and DAPSA $28^{[28]}$ at the baseline and at the last visit.

We used DAPSA28 score, including 28 joint counts and not the comprehensive 66/68 joint counts, a correlation was shown with DAPSA. We calculated DAPSA28 $=(28 \mathrm{TJC} \times 1.6)+(28 \mathrm{SJC} \times 1.6)+$ patient global (0-10VAS)+pain (0-10VAS)+CRP (mg/dL). ${ }^{[29]}$

Also, the patient's current treatment regimens including bDMARDs (adalimumab, certolizumab, etanercept, golimumab, infliximab, secukinumab, ustekinumab and tofacitinib), concomitant csDMARDs [methotrexate (MTX), leflunomide (LEF), sulphasalazine (SLZ)] and glucocorticoid (GC) were noted.

Obese and non-obese PsA patients who were on their first bDMARDs treatment were compared in terms of drug retention rate.

Our study was conducted in accordance with the Declaration of Helsinki and was approved by the ethics committee of Hacettepe University (approval number: GO21/164, date: 02.02.2021).

\section{Statistical Analyses}

All data were analyzed using the Statistical Package for the Social Sciences for Windows, Version 22.0 (IBM Corp., Armonk, NY, USA). The variables were investigated using visual (histogram and probability plots) and analytical methods (Kolmogorov-Smirnov, skewness, and kurtosis) to determine if they were normally distributed. Normally distributed variables were expressed as mean and standard deviation and non-normally distributed variables were expressed as median and interquartile range. Categorical variables were presented as absolute frequencies and percentages (\%). The chi-square test or Fisher's exact test was used to analyze differences between categorical data, if needed. The Student's t-test and the Mann-Whitney U test were used to compare the normally- and non-normally distributed continuous variables between two groups, respectively.
Retention rates of bDMARDs were assessed by the Kaplan-Meier survival analysis for two groups according to a change in the first bDMARDs. The differences between survival curves were determined by the log-rank test. A $5 \%$ type-I error level was used to infer statistical significance.

\section{Results}

\section{General Features}

The obese group was older at the age of psoriasis diagnosis $(33.5 \pm 14.3$ vs $30.3 \pm 13.5$ years, $\mathrm{p}=0.05)$, and had lower PsA disease duration ( 7 and 9 years, respectively, $\mathrm{p}=0.01$ ). While there was no difference between the two groups in terms of axial involvement, peripheral involvement (ever), smoking (ever), HLA B-27 positivity, uveitis and IBD, diabetes mellitus and hypertension were more common in the obese group (Table 1).

Before starting bDMARDs, 102 obese patients $(60 \%)$ and 105 non-obese patients (62\%) were using at least $1 \mathrm{mg}$ and above $\mathrm{GC}(\mathrm{p}=0.7)$. Moreover, the use of csDMARDs for obese and non-obese PsA patients were similar (MTX 82\% vs $75 \%$, SLZ $56 \%$ vs $61 \%$, LEF $30 \%$ vs $32 \%$, respectively; $\mathrm{p}>0.05$ ).

The first and last bDMARDs of the patients are shown in Figure 2. Among the first started bDMARDs percentages for obese and non-obese PsA patients were adalimumab 46

Table 1. Baseline demographic and clinical parameters by BMI categories

\begin{tabular}{|c|c|c|c|}
\hline & $\begin{array}{l}\mathrm{BMI} \geq 30 \\
\mathrm{n}=170\end{array}$ & $\begin{array}{l}\text { BMI }<30 \\
n=170\end{array}$ & p-value \\
\hline Age, years, mean $\pm S D$ & $50.6 \pm 10.8$ & $50.4 \pm 11.1$ & 0.9 \\
\hline Age at PsA, years, mean $\pm S D$ & $42.4 \pm 11.4$ & $40.8 \pm 10.9$ & 0.21 \\
\hline Age at Pso, years, mean \pm SD & $33.5 \pm 14.3$ & $30.3 \pm 13.5$ & $0.05^{\star}$ \\
\hline $\begin{array}{l}\text { PsA disease duration, years, } \\
\text { median (IQR) }\end{array}$ & $7(8)$ & $9(8)$ & $0.01 *$ \\
\hline Female, n (\%) & $125(74)$ & $125(74)$ & 1 \\
\hline $\begin{array}{l}\text { Peripheral involvement (ever), } \\
n(\%)\end{array}$ & $140(82)$ & $137(81)$ & 0.68 \\
\hline Axial involvement, n (\%) & $56(33)$ & $53(31)$ & 0.73 \\
\hline Smoking (ever) n, (\%) & $97(57.4)$ & $107(63.3)$ & 0.27 \\
\hline HLA B-27 (positive/total, \%) & $8 / 58(14)$ & 16/61 (26) & 0.09 \\
\hline PsA/Pso family history $n,(\%)$ & $72(42)$ & $58(34)$ & 0.13 \\
\hline Uveitis, n (\%) & $3(1.8)$ & $5(3)$ & 0.5 \\
\hline IBD, n (\%) & $3(1.8)$ & $5(3)$ & 0.5 \\
\hline \multicolumn{4}{|l|}{ Comorbidity, n (\%) } \\
\hline Diabetes mellitus & $30(18)$ & $14(8)$ & $0.01 *$ \\
\hline Hypertension & $55(32)$ & $25(15)$ & $<0.001$ * \\
\hline Hyperlipidemia & $15(9)$ & $11(7)$ & 0.41 \\
\hline Thyroid diseases & $15(9)$ & $16(9)$ & 0.85 \\
\hline \multicolumn{4}{|c|}{${ }^{*} p<0.05$ Data were given as mean (standard deviation) or median (IQR) } \\
\hline \multicolumn{4}{|c|}{$\begin{array}{l}\text { BMI: Body mass index, IBD: Inflammatory bowel disease, IQR: Inter-quartile range } \\
\text { PSA: Psoriatic arthritis, PSO: Psoriasis, SD: Standard deviation }\end{array}$} \\
\hline
\end{tabular}


vs 45 , etanercept 18 vs 19 , infliximab 14 vs 21 , golimumab 7 vs 8 , certolizumab 12 vs 5 , secukinumab 1 vs 0 , ustekinumab 2 vs 2 , respectively, and they were similar $(\mathrm{p}=0.23) .88$ (52\%) patients in the obese group and $78(46 \%)$ patients in the non-obese group had bDMARDs switching, and there was no significant difference between the groups $(\mathrm{p}=0.28)$. The last bDMARDs percentages for obese and non-obese PsA patients were adalimumab 35 vs 37 , etanercept 9 vs 12 , infliximab 12 vs 13 , golimumab 5 vs 7 , certolizumab 17 vs

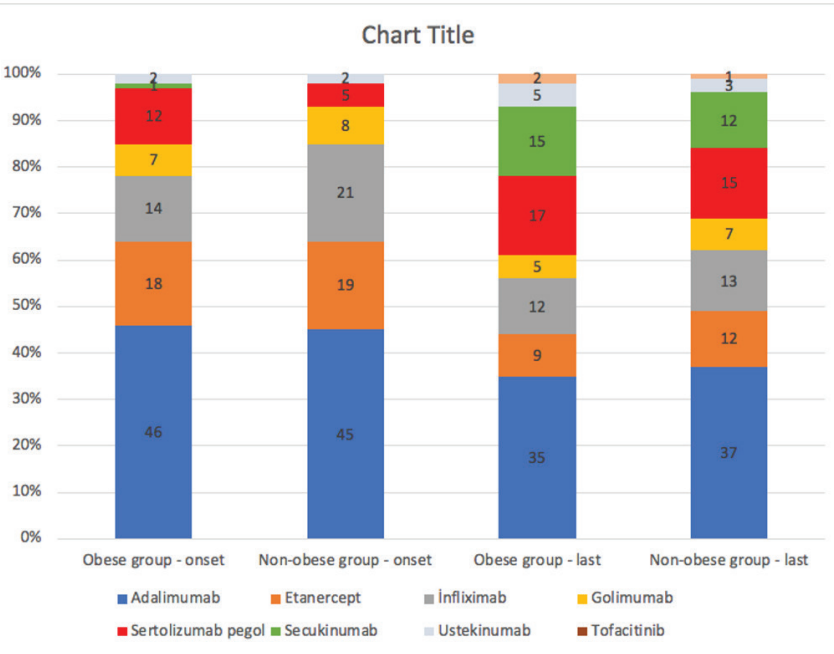

Figure 2. Distribution of the first and last bDMARDs by BMI categories DDMARDs: Biological disease-modifying antirheumatic drugs, BMI: Body mass index

15 , secukinumab 15 vs 12 , ustekinumab 5 vs 5 , tofacitinib 2 vs 1 , respectively, and they were similar ( $\mathrm{p}=0.94)$.

\section{Favorable Response to bDMARDs Treatment}

Baseline and last visit disease activity by BMI categories are shown in Table 2, Table 3 and Figure 3. DAS28, BASFI, DAPSA28 scores and PGA-VAS were significantly higher in the obese group than in the non-obese group at the onset of bDMARDs $(\mathrm{p}<0.05)$. Obese patients had more HDA than non-obese patients according to both DAS-28 and DAPSA28 classification at the baseline. Also, the median scores of DAS28, BASDAI, BASFI, PSAID-12, HAQ-DI, and PGAVAS in the obese group were significantly higher than in the non-obese group at the last visit. On the other hand, there was no difference in disease activity classification between the two groups according to DAS-28 and DAPSA28.

However, there was no significant difference between the levels recorded at the last visit and the baseline level in PSAID-12, DAS-28, BASDAI and PGA-VAS scores of both obese and non-obese groups.

There was no significant difference between the PsA subgroups in the retention rates of the first bDMARDs.
Table 2. Baseline treatment and disease activity by BMI categories

\begin{tabular}{|c|c|c|c|}
\hline & $\begin{array}{l}\mathrm{BMI} \geq 30 \\
\mathrm{n}=170\end{array}$ & $\begin{array}{l}\mathrm{BMI}<30 \\
\mathrm{n}=170\end{array}$ & p-value \\
\hline Use of steroid, n (\%) & $102(60)$ & $105(62)$ & 0.68 \\
\hline \multicolumn{4}{|l|}{ Using csDMARDs, n (\%) } \\
\hline - Methotrexate & $140(82)$ & $126(75)$ & 0.08 \\
\hline - Sulfasalazine & $95(56)$ & $104(61)$ & 0.29 \\
\hline - Leflunomide & $51(30)$ & $54(32)$ & 0.69 \\
\hline $\begin{array}{l}\text { Swollen joint count (28 joints), } \\
\text { median (IQR) }\end{array}$ & $1(4)$ & $0.5(2)$ & 0.13 \\
\hline $\begin{array}{l}\text { Tender joint count ( } 28 \text { joints), } \\
\text { median (IQR) }\end{array}$ & $4(8)$ & $2(4)$ & $0.039^{*}$ \\
\hline ESR (mm/hr), median (IQR) & $22(24)$ & $19.5(25)$ & 0.61 \\
\hline CRP (mg/L), median (IQR) & $1.1(1.3)$ & $0.94(1.1)$ & 0.13 \\
\hline DAPSA28 score, median (IQR) & $23.5(18.8)$ & $18.8(11.3)$ & $0.001 *$ \\
\hline \multicolumn{3}{|c|}{ DAPSA28 disease activity classification, $\mathrm{n}(\%)$} & $0.007^{*}$ \\
\hline - Remission & $2(2)$ & 0 & \\
\hline - LDA & $17(17)$ & $28(33)$ & \\
\hline - MDA & $42(41)$ & $38(45)$ & \\
\hline - HDA & $41(40)$ & $18(21)$ & \\
\hline PSAID-12 score, median (IQR) & $6.1(3.1)$ & $5.6(2.8)$ & 0.21 \\
\hline DAS-28 score, mean \pm SD & $4.5(2.05)$ & $3.7(1.9)$ & $0.003^{*}$ \\
\hline \multicolumn{3}{|c|}{ DAS-28 disease activity classification, $\mathrm{n}(\%)$} & $0.012^{*}$ \\
\hline - Remission & $10(10)$ & $17(19)$ & \\
\hline - LDA & $16(15)$ & $17(19)$ & \\
\hline - MDA & $47(45)$ & $44(49)$ & \\
\hline - HDA & $32(31)$ & $11(12)$ & \\
\hline BASDAI, median (IQR) & $6.7(3.2)$ & $5.8(3)$ & 0.08 \\
\hline BASFI, median (IQR) & $5.2(4.9)$ & $3.7(3.6)$ & $0.004^{*}$ \\
\hline HAQ-DI score, median (IQR) & $0.75(0.85)$ & $0.6(0.65)$ & 0.058 \\
\hline PGA-VAS, median (IQR) & $70(30)$ & $60(30)$ & $0.001 *$ \\
\hline \multicolumn{4}{|l|}{${ }^{*} p<0.05$} \\
\hline \multicolumn{4}{|c|}{ Data were given as mean (standard deviation) or median (IQR). } \\
\hline \multicolumn{4}{|c|}{$\begin{array}{l}\text { BASDAl: Bath Ankylosing Spondylitis Disease Activity Index, BASFI: Bath Ankylosing } \\
\text { Spondylitis Functional Index, BMI: Body mass index, CRP: C-reactive protein, } \\
\text { CSDMARDs: Conventional synthetic disease modifying anti-rheumatic drugs, } \\
\text { DAPSA: Disease Activity index for psoriatic arthritis, DAS: Disease Activity score, } \\
\text { ESR: Erythrocyte sedimentation rate, HAQ-DI: Health Assessment Questionnaire } \\
\text { Disability Index, HDA: High disease activity, hr: Hour; IQR: Inter-quartile range, } \\
\text { LDA: Low disease activity, MDA: Moderate disease activity, PGA-VAS: Patient global } \\
\text { assessment-visual analogue Scale, PSAID: Psoriatic Arthritis Impact of Disease, SD: } \\
\text { Standard deviation }\end{array}$} \\
\hline
\end{tabular}

However, it was very close to the significance value (logrank, $\mathrm{p}=0.055$ ). The median retention rate of bDMARDs in the obese and non-obese groups was 35 and 65 months, respectively (Figure 4).

\section{Discussion}

In the HUR-BIO registry, nearly half of PsA patients had obesity (42\%). Some of the patient-reported outcomes (PROs) were higher in the obese group than in the nonobese group at the beginning of bDMARDs treatment and last visit. However, the change from baseline in these parameters at the final visit was similar in the two groups. 
Table 3. Last visit treatment and disease activity by BMI categories

\begin{tabular}{|c|c|c|c|}
\hline & $\begin{array}{l}\mathrm{BMI} \geq 30 \\
\mathrm{n}=170\end{array}$ & $\begin{array}{l}\mathrm{BMI}<30 \\
\mathrm{n}=170\end{array}$ & p-value \\
\hline $\begin{array}{l}\text { Follow-up period, month, median } \\
\text { (IQR) }\end{array}$ & $27.8(50.6)$ & $39.2(73.2)$ & $0.029 *$ \\
\hline ESR (mm/hr), median (IQR) & $17(21)$ & $17(19.5)$ & 0.43 \\
\hline CRP (mg/L), median (IQR) & $0.57(0.8)$ & $0.44(0.6)$ & $0.012 *$ \\
\hline DAPSA-28 score, median (IQR) & $11.2(13)$ & $8.7(12.4)$ & 0.073 \\
\hline$\triangle \mathrm{DAPSA} 28$ score, median (IQR) & $15.4(17)$ & $8.2(14)$ & 0.068 \\
\hline \multicolumn{2}{|c|}{ DAPSA28 disease activity classification, $\mathrm{n}(\%)$} & & 0.23 \\
\hline - Remission & $31(23)$ & $47(34)$ & \\
\hline - LDA & $60(44)$ & $52(37)$ & \\
\hline - MDA & $36(26)$ & $31(22)$ & \\
\hline$-H A D$ & $10(7)$ & $9(7)$ & \\
\hline $\begin{array}{l}\text { DAPSA28 50\% response, positive/ } \\
\text { total (\%) }\end{array}$ & 43/74 (58) & $31 / 61(51)$ & 0.4 \\
\hline PSAID-12 score, median (IQR) & $4.3(4.1)$ & $3.1(4.2)$ & $0.022^{*}$ \\
\hline$\triangle P S A I D-12$ score, median (IQR) & $1.7(3.7)$ & $2.4(4)$ & 0.47 \\
\hline$\triangle$ PSAID-12 $\geq 3$, positive/total (\%) & $17 / 60(28)$ & 22/57 (39) & 0.24 \\
\hline DAS-28 score, median (IQR) & $2.9(1.7)$ & $2.6(1.7)$ & $0.026 *$ \\
\hline$\triangle \mathrm{DAS}-28$, median (IQR) & $1.5(2.1)$ & $1.1(1.3)$ & 0.17 \\
\hline \multicolumn{2}{|c|}{ DAS-28 disease activity classification, $\mathrm{n}(\%)$} & & 0.15 \\
\hline Remission & $68(42)$ & $77(50)$ & \\
\hline LDA & $24(15)$ & $29(19)$ & \\
\hline MDA & $57(35)$ & $41(27)$ & \\
\hline HAD & $13(8)$ & $7(5)$ & \\
\hline$\Delta$ DAS-28 $\geq 1.2$, positive/total (\%) & 45/77 (58) & $31 / 67(46)$ & 0.14 \\
\hline BASDAI, median (IQR) & $4.5(4.2)$ & $3.5(4.6)$ & $0.003^{*}$ \\
\hline$\triangle \mathrm{BASDAl}$, mean $\pm \mathrm{SD}$ & $2.3 \pm 2.6$ & $2.7 \pm 2.8$ & 0.35 \\
\hline $\begin{array}{l}\triangle \mathrm{BASDAl} \geq 20 \mathrm{~mm}, \text { positive/total } \\
(\%)\end{array}$ & $38 / 73(52)$ & $45 / 75(60)$ & 0.33 \\
\hline $\begin{array}{l}\text { BASDAI50 response, positive/total } \\
(\%)\end{array}$ & $33 / 100(33)$ & $41 / 94(44)$ & 0.13 \\
\hline BASFI, median (IQR) & $3.3(4.8)$ & $2.3(3.8)$ & $<0.001 *$ \\
\hline HAQ-DI score, median (IQR) & $0.5(0.9)$ & $0.35(0.8)$ & $0.021 *$ \\
\hline HAQ-DI score $<0.5$ units, $n$ (\%) & $79(50)$ & $101(63)$ & $0.019 *$ \\
\hline$\Delta \mathrm{HAQ}-\mathrm{DI} \geq 0.22$, positive/total $(\%)$ & $39 / 90(43)$ & $37 / 81(44)$ & 0.76 \\
\hline PGA-VAS, median (IQR) & $50(40)$ & $40(40)$ & $0.012^{*}$ \\
\hline$\Delta \mathrm{PGA} \geq 20 \mathrm{~mm}$, positive/total (\%) & $56 / 91(62)$ & $53 / 93(57)$ & 0.53 \\
\hline \multicolumn{4}{|l|}{${ }^{*} p<0.05$} \\
\hline \multicolumn{4}{|c|}{ Data were given as mean (standard deviation) or median (IQR). } \\
\hline \multicolumn{4}{|c|}{$\begin{array}{l}\text { BASDAI: Bath Ankylosing Spondylitis Disease Activity Index, BASFI: Bath Ankylosing } \\
\text { Spondylitis Functional Index, BMI: Body mass index, CRP: C-reactive protein, DAPSA: } \\
\text { Disease Activity Index for Psoriatic Arthritis, DAS: Disease Activity Score, ESR: Erythrocyte } \\
\text { sedimentation rate, HAQ-DI: Health Assessment Questionnaire Disability Index, HDA: } \\
\text { High disease activity, IQR: Inter-quartile range, LAD: Low disease activity, MDA: Moderate } \\
\text { disease activity, PGA-VAS: Patient global assessment-visual analogue scale, PSAID: Psoriatic } \\
\text { Arthritis Impact of Disease, SD: Standard deviation }\end{array}$} \\
\hline
\end{tabular}

The distribution, switching and the retention rates of the first bDMARDs were similar in the groups.

Obesity is common in PsA patients compared to patients with psoriasis or other inflammatory diseases or general population. ${ }^{[30]}$ There is a complex and bidirectional relationship between obesity and PsA. Obesity may be

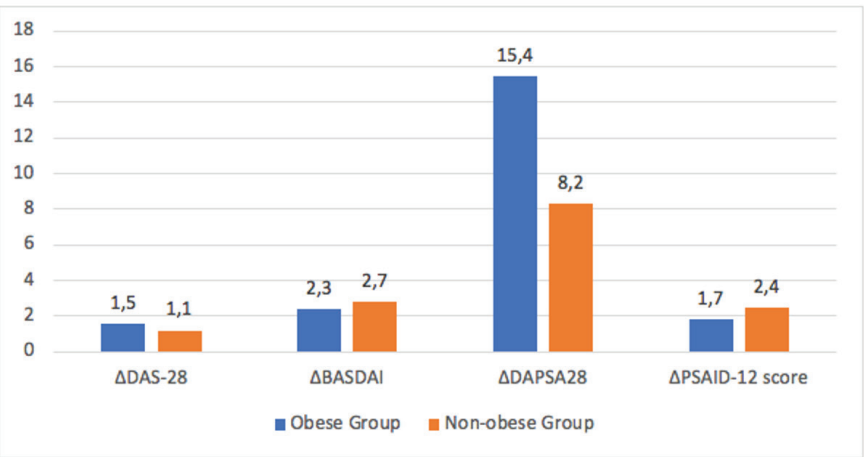

Figure 3. Significant change of disease activity by BMI categories BASDAI: Bath Ankylosing Spondylitis Disease Activity Index, BMI: Body mass index, DAPSA: Disease Activity index for Psoriatic Arthritis, DAS: Disease Activity score, PSAID: Psoriatic Arthritis Impact of Disease

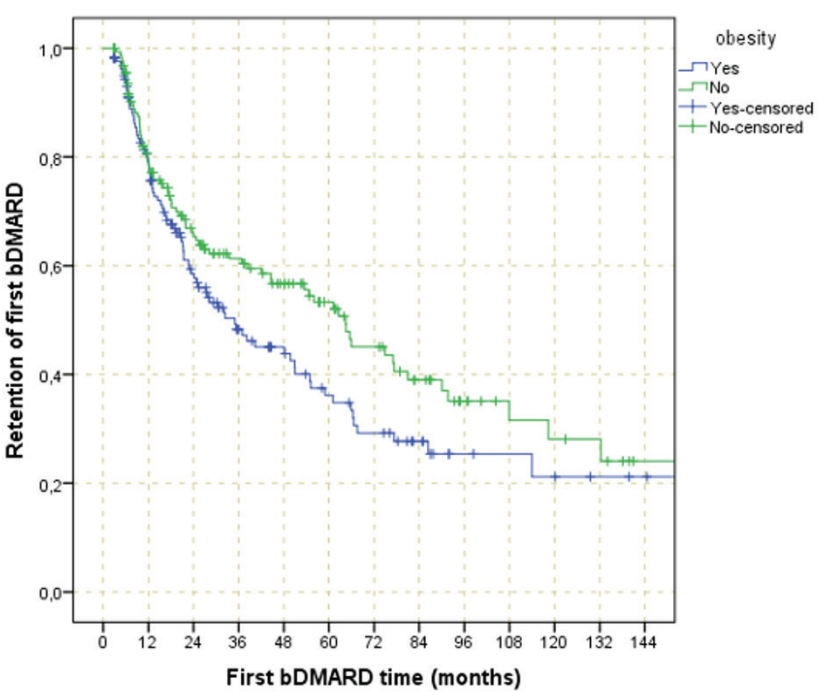

Figure 4. Retention rate for bDMARDs by BMI categories DDMARDs: Biological disease modifying anti-rheumatic drugs Log rank $p$-value between $B M I \geq 30 \mathrm{~kg} / \mathrm{m}^{2}$ and $<30 \mathrm{~kg} / \mathrm{m}^{2}: 0.055$ Median of retention rate of first bDMARDs: $B M l \geq 30 \mathrm{~kg} / \mathrm{m}^{2}$ and $<30 \mathrm{~kg} / \mathrm{m}^{2} 35$ and 65 months, respectively

an important risk factor for the development of PsA from psoriasis. ${ }^{[31]}$ On the other hand, PsA patients may become obese due to less physical activity because of joint involvement. ${ }^{[8]}$ The prevalence of obesity in PsA patients in studies varies between $30 \%$ and $45 \%$, depending on the study design. ${ }^{[32-37]}$ Prevalence of obesity in PsA patients in the current study was consistent with the literature.

Obesity is associated with treatment response and discontinuation rates of disease-modifying antirheumatic drugs (DMARDs) of PsA patients. ${ }^{[38]}$ On the other hand, bDMARDs and targeted synthetic agents (tsDMARDs) may affect the body weight and body composition of PsA patients. ${ }^{[39]}$ In our study, age- and sex-matched obese PsA patients had higher DAPSA, DAS28, PGA-VAS, BASFI than non-obese PsA patients at the beginning of bDMARDs treatment. In the similar study from DANBIO and ICEBIO 
registries, ${ }^{[9]}$ obese PsA patients had higher baseline disease activity measures than non-obese patients at the beginning of bDMARDs treatment. In another similar study, ${ }^{[40]}$ obesity was shown to be associated with higher PSAID12 and Routine Assessment of Patient Index Data 3 (RAPID3) scores. A systematic literature review found that obesity might have a negative impact on related PROs such as function and pain. ${ }^{[30]}$ We found worse outcomes in some PROs, including function and disease activity, in obese PsA patients at the beginning of bDMARDs treatment. The cause of this condition appears to be related to the additional chronic low-grade inflammatory condition caused by obesity and by release of cytokines, chemokines and adipokines. ${ }^{[39]}$ In addition, obesity may cause loss of function independent of inflammation and PsA.

In the current study, PSAID12, DAS28, BASDAI, BASFI, HAQ and PGA-VAS scores of obese patients were higher than those of non-obese patients at the last visit of PsA patients who were started on bDMARDs treatment. However, there was no difference in terms of change in disease activity parameters from baseline (DDAPSA28, $\triangle$ PSAID-12 score, $\triangle \mathrm{DAS}-28, \triangle \mathrm{BASDAI}$ ) and significant response (DAPSA2 $80 \%$ response, $\triangle$ PSAID- $12 \geq 3, \triangle$ DAS$28 \geq 1.2$, BASDAI50 response, $\triangle \mathrm{PGA} \geq 20 \mathrm{~mm}$ ) at the last visit of obese and non-obese PsA patients. While the effect of obesity on treatment response in PsA patients is negative in some studies in the literature, very few studies have shown no effect. Various studies have demonstrated that obesity has a negative effect on achieving LDA or remission. ${ }^{[6,7,41]}$ Two systematic reviews and meta-analyses have highlighted that obesity is a predictor of inferior response to tumor necrosis factor inhibitor (TNFi) in patients with PsA. ${ }^{[42,43]}$ Limited data are available with other bDMARDs. In a prospective study by Pantano et al..$^{[44]}$ on PsA patients, who were started on secukinumab, the DAPSA score was found to be better in obese/overweight patients at 6 months compared to normal weight patients. In a post hoc analysis of phase III trials, obesity was found not to affect treatment response in PsA patients using abatacept. ${ }^{[45]}$ In another prospective study, ${ }^{[9]}$ the proportion of EULAR's good and moderate treatment response is higher in obese PsA patients than in non-obese PsA patients at the sixth month, while there is no difference between obese and non-obese patients in ACR 20/50/70 response. Additionally, in a retrospective study, ${ }^{[46]}$ disease activity and clinical response to TNFi treatment in PsA, except for HAQ, were not affected by BMI. In our study, although initial disease activity and functions were worse in the obese group, there was no significant difference in treatment responses in our study. This may be due to the increased use of IL-17i at the final visit compared to baseline.
Further clinical prospective trials are needed to completely assess the impact of obesity on the outcomes of PsA patients who are started on bDMARDs.

There are few studies evaluating the effect of obesity on retention rates in PsA patients using bDMARDs. There was no significant difference between the PsA subgroups in the retention rates of the first bDMARDs, although it was very close to the significance value. In the current study, retention rates at 12-month follow-up of first bDMARDs of obese and non-obese PsA patients were $79 \%$ and $78 \%$, respectively. In a multicenter study ${ }^{[47]}$ the median 12 -month retention rate of the first $\mathrm{TNFi}$ was $77 \%$, and our results were in line with this study. Anti-IL17A and anti-IL12/23 drugs have been shown to have drug retention comparable to TNFi in real-life data. ${ }^{[48-50]}$ In the study of Hojgaard et al., ${ }^{[9]}$ they found that the median drug adherence was longer among non-obese patients compared to obese patients and obesity increased the risk of withdrawal of TNFi (hazard ratio 1.6). Conversely, in a retrospective study by Lorenzin et al. ${ }^{[51]}$ in which they investigated the factors affecting drug retention in PsA, BMI was not found to be associated with the risk of first bDMARDs withdrawal. An important result of our study is that, despite the additional inflammatory burden caused by obesity, it can be concluded that there is no difference in terms of drug retention rates in obese patients compared to non-obese patients. However, more clinical studies are needed to better understand this.

Considering the effect of obesity on treatment response and drug retention, it seems logical to recommend weight loss to obese PsA patients. In a systematic review, ${ }^{[52]}$ it has been emphasized that although the evidence is limited, weight loss in PsA may be associated with less inflammation. How much weight should be lost has also been discussed in some studies. In a prospective study, ${ }^{[53]} \geq 5 \%$ weight loss from baseline was associated with a higher minimal disease activity success rate in overweight/obese patients with PsA who started treatment with TNFi. In the study by Weijers et al., ${ }^{[54]}$ PsA patients with a weight loss of $>10 \%$ of their body mass had the median DAS28 joint score decreased by 0.9 , and there was an increase in the percentage of patients achieving remission from $6 \%$ to $63 \%$. In a prospective study by Klingberg et al., ${ }^{[5]}$ weight loss in obese PsA patients with a very low-energy diet resulted in a significant improvement in most disease activity parameters and PROs, and it was concluded that weight loss was associated with significant positive effects on disease activity in joints, entheses and skin in obese PsA patients. In the disease management of obese PsA patients, weight loss may be helpful in reducing inflammatory burden, obtaining better treatment response and higher drug retention. 
There are some limitations of this study to be mentioned: First of all, the sample size was small and the study had a retrospective design. Additionally, due to the nature of reallife data, some patients had missing data on some parameters. The strength of our study is that it presented real-life data of obese PsA patients and contributes to the literature by evaluating the treatment response and especially retention rate of bDMARDs of these patients.

\section{Conclusion}

The prevalence of obesity in our PsA database was consistent with the literature. Although the baseline disease activity and functions were worse in age- and sex-matched obese PsA patients than in the non-obese group, there was no significant difference in treatment responses, except HAQ and BASFI. Although bDMARDs retention rates of the two groups were statistically similar, they were very close to significance level and lower in obese patients. We suggest weight loss in obese PsA patients as it may reduce the inflammatory burden, resulting in better function and retention of bDMARDs.

\section{Ethics}

Ethics Committee Approval: Our study was conducted in accordance with the Declaration of Helsinki and was approved by the ethics committee of Hacettepe University (approval number: GO21/164, date: 02.02.2021).

Informed Consent: Retrospective study.

Peer-review: Externally peer-reviewed.

\section{Authorship Contributions}

Concept: B.F., G.K.Y., A.S., B.A., E.B., E.Ç.B., E.D., G.A., Z.Ö., G.S.U., L.K., A.A., Ö.K., S..A.B., A.İ.E., S.K., U.K., Design: B.F., G.K.Y., A.S., B.A., E.B., E.Ç.B., E.D., G.A., Z.Ö., G.S.U., L.K., A.A., Ö.K., S..A.B., A.İ.E., S.K., U.K., Data Collection or Processing: B.F., G.K.Y., A.S., B.A., E.B., E.C..B., E.D., G.A., Z.Ö., G.S.U., L.K., A.A., Ö.K., S.A.B., A.İ.E., S.K., U.K., Analysis or Interpretation: B.F., G.K.Y., A.S., B.A., E.B., E.Ç.B., E.D., G.A., Z.Ö., G.S.U., L.K., A.A., Ö.K., Ş.A.B., A.İ.E., S.K., U.K., Literature Search: B.F., G.K.Y., A.S., B.A., E.B., E.Ç.B., E.D., G.A., Z.Ö., G.S.U., L.K., A.A., Ö.K., S..A.B., A.İ.E., S.K., U.K., Writing: B.F., G.K.Y., A.S., B.A., E.B., E.Ç.B., E.D., G.A., Z.Ö., G.S.U., L.K., A.A., Ö.K., S..A.B., A.İ.E., S.K., U.K.

Conflict of Interest: No conflict of interest was declared by the authors.

Financial Disclosure: The authors declare that they have no relevant financial.

\section{References}

1. Ogdie A, Coates LC, Gladman DD. Treatment guidelines in psoriatic arthritis. Rheumatology (Oxford) 2020;59(Suppl 1):i37-46.

2. D'Angelo S, Tramontano G, Gilio M, Leccese P, Olivieri I. Review of the treatment of psoriatic arthritis with biological agents: choice of drug for initial therapy and switch therapy for non-responders. Open Access Rheumatol 2017;9:21-8.

3. Gupta S, Syrimi Z, Hughes DM, Zhao SS. Comorbidities in psoriatic arthritis: a systematic review and meta-analysis. Rheumatol Int 2021;41:275-84.

4. Thomsen RS, Nilsen TI, Haugeberg G, Gulati AM, Kavanaugh A, Hoff M. Adiposity and physical activity as risk factors for developing psoriatic arthritis: longitudinal data from a Population-Based study in Norway. Arthritis Care Res (Hoboken) 2021;73:432-41.

5. Green A, Shaddick G, Charlton R, et al. Modifiable risk factors and the development of psoriatic arthritis in people with psoriasis. Br J Dermatol 2020;182:714-20.

6. Eder L, Thavaneswaran A, Chandran V, Cook RJ, Gladman DD. Obesity is associated with a lower probability of achieving sustained minimal disease activity state among patients with psoriatic arthritis. Ann Rheum Dis 2015;74:813-7.

7. di Minno MN, Peluso R, Iervolino S, et al. Obesity and the prediction of minimal disease activity: a prospective study in psoriatic arthritis. Arthritis Care Res (Hoboken) 2013;65:141-7.

8. Kumthekar A, Ogdie A. Obesity and psoriatic arthritis: a narrative review. Rheumatol Ther 2020;7:447-56.

9. Hojgaard P, Glintborg B, Kristensen LE, Gudbjornsson B, Love TJ, Dreyer L. The influence of obesity on response to tumour necrosis factor-alpha inhibitors in psoriatic arthritis: results from the DANBIO and ICEBIO registries. Rheumatology (Oxford) 2016;55:2191-9.

10. Nikiphorou E, Buch MH, Hyrich KL. Biologics registers in RA: methodological aspects, current role and future applications. Nat Rev Rheumatol 2017;13:503-10.

11. Deurenberg P, Weststrate JA, Seidell JC. Body mass index as a measure of body fatness: age- and sex-specific prediction formulas. Br J Nutr 1991;65:105-14.

12. Clinical guidelines on the identification, evaluation, and treatment of overweight and obesity in adults: executive summary. Expert Panel on the Identification, Evaluation, and Treatment of Overweight in Adults. Am J Clin Nutr 1998;68:899-917.

13. Garrett S, Jenkinson T, Kennedy LG, Whitelock H, Gaisford P, Calin A. A new approach to defining disease status in ankylosing spondylitis: the Bath Ankylosing Spondylitis Disease Activity Index. J Rheumatol 1994;21:2286-91.

14. Calin A, Garrett S, Whitelock H, et al. A new approach to defining functional ability in ankylosing spondylitis: the development of the Bath Ankylosing Spondylitis Functional Index. J Rheumatol 1994:21:2281-5.

15. Cauli A, Gladman DD, Mathieu A, et al. Patient global assessment in psoriatic arthritis: a multicenter GRAPPA and OMERACT study. J Rheumatol 2011;38:898-903.

16. Braun J, Pham T, Sieper J, et al. International ASAS consensus statement for the use of anti-tumour necrosis factor agents in patients with ankylosing spondylitis. Ann Rheum Dis $2003 ; 62: 817-24$.

17. Prevoo ML, van 't Hof MA, Kuper HH, van Leeuwen MA, van de Putte LB, van Riel PL. Modified disease activity scores that include twenty-eight-joint counts. Development and validation 
in a prospective longitudinal study of patients with rheumatoid arthritis. Arthritis Rheum 1995;38:44-8.

18. Gossec L, de Wit M, Kiltz U, et al. A patient-derived and patientreported outcome measure for assessing psoriatic arthritis: elaboration and preliminary validation of the Psoriatic Arthritis Impact of Disease (PsAID) questionnaire, a 13-country EULAR initiative. Ann Rheum Dis 2014;73:1012-9.

19. Schoels M, Aletaha D, Funovits J, Kavanaugh A, Baker D, Smolen JS. Application of the DAREA/DAPSA score for assessment of disease activity in psoriatic arthritis. Ann Rheum Dis 2010;69:1441-7.

20. Schoels MM, Aletaha D, Alasti F, Smolen JS. Disease activity in psoriatic arthritis (PsA): defining remission and treatment success using the DAPSA score. Ann Rheum Dis 2016;75:811-8.

21. Kalyoncu U, Kiraz S, Bilgen SA, et al. Change in PsAID-12 scores in patients continuing or discontinuing anti-TNF treatments in psoriatic arthritis: results from the HUR-BIO biologic registry. Clin Rheumatol 2019;38:1187-92.

22. Wells G, Becker JC, Teng J, et al. Validation of the 28-joint Disease Activity Score (DAS28) and European League Against Rheumatism response criteria based on C-reactive protein against disease progression in patients with rheumatoid arthritis, and comparison with the DAS28 based on erythrocyte sedimentation rate. Ann Rheum Dis 2009;68:954-60.

23. Braun J, Pham T, Sieper J, et al. International ASAS consensus statement for the use of anti-tumour necrosis factor agents in patients with ankylosing spondylitis. Ann Rheum Dis 2003;62:817-24.

24. Fries JF, Spitz PW, Young DY. The dimensions of health outcomes: the health assessment questionnaire, disability and pain scales. J Rheumatol 1982;9:789-93.

25. Wells G, Tugwell P, Kraag G, Baker P, Groh J, Redelmeier D. Minimum important difference between patients with rheumatoid arthritis: the patient's perspective. J Rheumatol 1993;20:557-60.

26. Felson DT, Smolen JS, Wells G, et al. American College of Rheumatology/European League Against Rheumatism provisional definition of remission in rheumatoid arthritis for clinical trials. Arthritis Rheum 2011;63:573-86.

27. Anderson J, Caplan L, Yazdany J, et al. Rheumatoid arthritis disease activity measures: American College of Rheumatology recommendations for use in clinical practice. Arthritis Care Res (Hoboken) 2012;64:640-7.

28. Smolen JS, Schoels M, Aletaha D. Disease activity and response assessment in psoriatic arthritis using the Disease Activity index for PSoriatic Arthritis (DAPSA). A brief review. Clin Exp Rheumatol 2015;33(5 Suppl 93):S48-50.

29. Michelsen B, Sexton J, Smolen JS, et al. Can disease activity in patients with psoriatic arthritis be adequately assessed by a modified Disease Activity index for PSoriatic Arthritis (DAPSA) based on 28 joints? Ann Rheum Dis 2018;77:1736-41.

30. Canete JD, Tasende JAP, Laserna FJR, Castro SG, Queiro R. The impact of comorbidity on patient-reported outcomes in psoriatic arthritis: a systematic literature review. Rheumatol Ther 2020;7:237-57.

31. Scher JU, Ogdie A, Merola JF, Ritchlin C. Preventing psoriatic arthritis: focusing on patients with psoriasis at increased risk of transition. Nat Rev Rheumatol 2019;15:153-66.

32. Husted JA, Thavaneswaran A, Chandran V, et al. Cardiovascular and other comorbidities in patients with psoriatic arthritis: a comparison with patients with psoriasis. Arthritis Care Res (Hoboken) 2011;63:1729-35.

33. Jafri K, Bartels CM, Shin D, Gelfand JM, Ogdie A. Incidence and management of cardiovascular risk factors in psoriatic arthritis and rheumatoid arthritis: a population-based study. Arthritis Care Res (Hoboken) 2017;69:51-7.

34. Ernste F, Sánchez-Menéndez M, Wilton K, Crowson C, Matteson EL, Maradit Kremers H. Cardiovascular risk profile at the onset of psoriatic arthritis: a population-based cohort study. Arthritis Care Res (Hoboken) 2015;67:1015-21.

35. Labitigan M, Bahce-Altuntas A, Kremer JM, et al. Higher rates and clustering of abnormal lipids, obesity, and diabetes mellitus in psoriatic arthritis compared with rheumatoid arthritis. Arthritis Care Res (Hoboken) 2014;66:600-7.

36. Bhole VM, Choi HK, Burns LC, et al. Differences in body mass index among individuals with PsA, psoriasis, RA and the general population. Rheumatology 2012;51:552-6.

37. Tam LS, Tomlinson B, Chu TT, et al. Cardiovascular risk profile of patients with psoriatic arthritis compared to controls--the role of inflammation. Rheumatology (Oxford) 2008;47:718-23.

38. Galíndez E, Carmona L. Is obesity in psoriatic arthritis associated with a poorer therapeutic response and more adverse effects of treatment with an anchor drug? Reumatol Clin 2016;12:307-12. (English, Spanish)

39. Toussirot E. The interrelations between biological and targeted synthetic agents used in inflammatory joint diseases, and obesity or body composition. Metabolites 2020;10:107.

40. Walsh JA, Wan MT, Willinger C, et al. Measuring outcomes in psoriatic arthritis: comparing routine assessment of patient index data and psoriatic arthritis impact of disease. J Rheumatol 2020;47:1496-505.

41. Ogdie A, Palmer JL, Greenberg J, et al. Predictors of achieving remission among patients with psoriatic arthritis initiating a tumor necrosis factor inhibitor. J Rheumatol 2019;46:475-82.

42. Singh S, Facciorusso A, Singh AG, et al. Obesity and response to anti-tumor necrosis factor-alpha agents in patients with select immune-mediated inflammatory diseases: a systematic review and meta-analysis. PLoS One 2018;13:e0195123. doi: 10.1371/journal. pone.0195123.

43. Shan J, Zhang J. Impact of obesity on the efficacy of different biologic agents in inflammatory diseases: a systematic review and meta-analysis. Joint Bone Spine 2019;86:173-83.

44. Pantano I, Iacono D, Favalli EG, et al. Secukinumab efficacy in patients with PsA is not dependent on patients' body mass index. Ann Rheum Dis 2020:annrheumdis-2020-217251. doi: 10.1136/ annrheumdis-2020-217251. Epub ahead of print.

45. McInnes IB, Ferraccioli G, D’Agostino MA, et al. Body mass index and treatment response to subcutaneous abatacept in patients with psoriatic arthritis: a post hoc analysis of a phase III trial. RMD Open 2019;5:e000934. doi: 10.1136/rmdopen-2019-000934.

46. Iannone F, Fanizzi R, Scioscia C, Anelli M, Lapadula G. Body mass does not affect the remission of psoriatic arthritis patients on antiTNF- $\alpha$ therapy. Scandinavian J Rheumatol 2013;42:41-4.

47. Brahe CH, Ornbjerg LM, Jacobsson L, et al. Retention and response rates in 14261 PsA patients starting TNF inhibitor treatment-results from 12 countries in EuroSpA. Rheumatology (Oxford) 2020;59:1640-50.

48. Eviatar T, Zisman D, Gendelman O, et al. Secukinumab real world drug retention compared to TNF-alpha inhibitors in psoriatic arthritis. Clin Exp Rheumatol 2021 Jan 7. Epub ahead of print. 
49. Ramonda R, Lorenzin M, Carriero A, et al. Effectiveness and safety of secukinumab in 608 patients with psoriatic arthritis in real life: a 24-month prospective, multicentre study. RMD Open 2021;7:e001519. doi: 10.1136/rmdopen-2020-001519.

50. Navarini L, Costa L, Tasso $M$, et al. Retention rates and identification of factors associated with anti-TNFalpha, anti-IL17, and anti-IL12/23R agents discontinuation in psoriatic arthritis patients: results from a real-world clinical setting. Clin Rheumatol 2020;39:2663-70.

51. Lorenzin M, Ortolan A, Cozzi G, et al. Predictive factors for switching in patients with psoriatic arthritis undergoing anti-TNFalpha, anti-IL12/23, or anti-IL17 drugs: a 15-year monocentric real-life study. Clin Rheumatol 2021;40:4569-80.

52. Almodovar R, Zarco P, Oton T, Carmona L. Effect of weight loss on activity in psoriatic arthritis: A systematic review. Reumatol Clin (Engl Ed) 2018;14:207-10.
53. Di Minno MN, Peluso R, Iervolino S, et al. Weight loss and achievement of minimal disease activity in patients with psoriatic arthritis starting treatment with tumour necrosis factor alpha blockers. Ann Rheum Dis 2014;73:1157-62.

54. Weijers JM, Müskens WD, van Riel PL. Effect of significant weight loss on disease activity: reason to implement this nonpharmaceutical intervention in daily clinical practice. RMD Open 2021;7:e001498. doi: 10.1136/rmdopen-2020-001498.

55. Klingberg E, Bilberg A, Bjorkman S, et al. Weight loss improves disease activity in patients with psoriatic arthritis and obesity: an interventional study. Arthritis Res Ther 2019;21:17. 